\title{
Diagnostic Problems in Chronic Basophilic Leukemia
}

\author{
Kronik Bazofilik Lösemide Tanısal Sorunlar
}

(D) Cavit Çehreli

Dokuz Eylül University Faculty of Medicine, Division of Hematology, Izmir, Turkey

\section{Abstract}

Chronic basophilic leukemia (CBL) is an extremely rare type of leukemia. A literature review revealed six cases reported as primary $\mathrm{CBL}$ and five patients with secondary CBL. Patients with primary $\mathrm{CBL}$ may present with symptoms not related to leukemia. Dysplastic changes in peripheral blood and bone marrow were described and demonstrated in cases of primary and secondary CBL. The literature review also revealed that differential counts made by automated blood cell counters may not characterize cells as basophils in patients with primary and secondary $\mathrm{CBL}$ and may mislead physicians in making a differential diagnosis. For these reasons, laboratory studies for the diagnosis of $\mathrm{CBL}$ are required, including metachromatic staining by toluidine blue and antigen expressions by flow cytometric analysis, to detect the nature of the neoplastic cells as basophils for a reliable diagnosis of $\mathrm{CBL}$. The literature review failed to reveal specific cytogenetic findings in patients with primary and secondary types of CBL.

Keywords: Myelodysplastic syndrome, Dysplasia, Interleukin-6, Chronic myeloid leukemia, Chronic basophilic leukemia, Mast cell leukemia

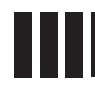

Öz

Kronik bazofilik lösemi (KBL) son derece nadir bir lösemi tipidir. Literatürün gözden geçirilmesi ile primer $\mathrm{KBL}$ olarak altı olgu ve sekonder KBL olarak beş olgu rapor edildiği görüldü. Primer KBL'li hastalar, lösemi ile ilgili olmayan yakınmalar ile başvurabilirler. Primer ve sekonder KBL hastalarının periferal kan ve kemik iliği yaymalarında anormal değişiklikler tanımlandı ve gösterildi. Literatür taraması, primer ve sekonder KBL hastalarında otomatik kan hücre sayıcıları tarafından yapılan ayırıcı sayımların hücreleri bazofil olarak karakterize edemeyeceğini ve doktorları ayırıcı tanıda yanıltabileceğini ortaya koymuştur. Bu nedenle güvenilir bir KBL tanısı için neoplastik hücre türünün bazofil olarak saptanması, toluidine mavisi ile metakromatik boyanmayı ve membranlarındaki antijen ekspresyonlarını akım sitometrik analizi ile yapan kanıtlayıcı laboratuvar incelemelerini gerektirir. Literatürün gözden geçirilmesi primer ve sekonder KBL hastalarında özel sitogenetik bulgular olmadığını göstermiştir.

Anahtar Sözcükler: Myelodisplastik sendrom, Displazi, Interleukin-6, Kronik myeloid lösemi, Kronik bazofilik lösemi, Mast hücre lösemi

\section{Introduction}

Basophils are one of the members of granulocytes in the myeloid lineage and are formed by proliferation and differentiation of committed myeloid progenitors. Basophils in peripheral blood (PB) or tissues range in size from 10 to $15 \mu \mathrm{m}$ and have nuclei that are purplish or dark blue and cytoplasmic granules of dark blue to purple and even blackish color as seen on Wright-stained PB and bone marrow (BM) smears [1]. A review of the international literature revealed 6 cases reported as primary chronic basophilic leukemia (CBL) $[2,3,4]$ and 5 cases reported as chronic myeloid leukemia $(\mathrm{CML})$ with transformation to $\mathrm{CBL}$, as a secondary $\mathrm{CBL}[5,6,7,8,9]$. The purpose of this review is to remind readers of the importance of diagnostic problems as automated blood cell counters (ABCCs) may not characterize cells as basophils in patients with primary and secondary $\mathrm{CBL}$, but may simply flag them $[3,4,9]$. The literature review failed to reveal lymphoma or non-hematologic neoplasia with transformation to secondary CBL.

Age and sex distribution, splenic size, presenting symptoms, results of complete blood counts, and cytogenetic and molecular studies in patients with primary and secondary CBL are shown in Table 1 and Table 2, respectively.

\section{Presenting Symptoms}

Presenting symptoms may not be related to leukemia, as in Case \#6 with primary $\mathrm{CBL}$ (Table 1). The patient presented with recurrent occurrence of febrile episodes and abdominal pain at about 8-week intervals, associated with simultaneous cyclic oscillation in neutrophil leukocyte counts and in the levels of C-reactive protein (CRP) when leukocyte counts climbed to the peak level and remained with the consumption of analgesics-antipyretics in

๑Copyright 2018 by Turkish Society of Hematology

Turkish Journal of Hematology, Published by Galenos Publishing House 


\begin{tabular}{|c|c|c|c|c|c|c|c|}
\hline Characteristics & Case 1 & Case 2 & Case 3 & Case 4 & Case 5 & Case 6 & $\begin{array}{l}\text { Case } 7 \\
\text { (Accelerated } \\
\text { phase of Case 6) }\end{array}$ \\
\hline Age/Sex & 30/Male & 67/Male & 52/Male & 32/Male & 81/Male & 68/Female & At the age of 73 \\
\hline $\begin{array}{l}\text { Presenting } \\
\text { symptoms }\end{array}$ & \begin{tabular}{|l|} 
Polyurea, \\
Diabetes \\
insipidus, \\
Polydisplasia, \\
Pituitary \\
lesion \\
\end{tabular} & \begin{tabular}{|l|} 
Progressive \\
fatigue, \\
Severe motor \\
neuropathy
\end{tabular} & $\begin{array}{l}\text { Progressive } \\
\text { fatigue, } \\
\text { Epigastric pain, } \\
\text { Pruritis } \\
\text { urticaria, } \\
\text { Weight loss } \\
\end{array}$ & Progressive fatigue & $\begin{array}{l}\text { Decrease } \\
\text { in appetite, } \\
\text { Weight loss }\end{array}$ & $\begin{array}{l}\text { Febrile episodes } \\
\text { occuring with } \\
\text { 8-week intervals } \\
\text { with abdominal } \\
\text { pain, Weight loss }\end{array}$ & $\begin{array}{l}\text { Febrile episodes } \\
\text { when basophil } \\
\text { count }>40 \times 10^{9} / \mathrm{L} \\
\text { with abdominal } \\
\text { pain }\end{array}$ \\
\hline Splenomegaly & Absent & Marked & Absent & Marked & $3-4 \mathrm{~cm}$ & Absent & $4 \mathrm{~cm}$ \\
\hline Hemoglobin (g/dL) & 11.1 & 12.6 & 13.2 & 9.1 & 10.5 & 11.2 & $5.7-7.1$ \\
\hline WBC $\left(\times 10^{9} / L\right)$ & 9.9 & 9.3 & 52.0 & 47.5 & 50.0 & 59.1 & $59-315$ \\
\hline Platelet $\left(\times 10^{9} / \mathrm{L}\right)$ & 200 & 319 & 227 & 240 & 874 & 226 & $134-41$ \\
\hline BM blast (\%) & 7 & 2 & 8 & 5 & NR & $<1$ & 6 \\
\hline BM basophil (\%) & 15 & 26 & 20 & NR & 40 & 75 & 51 \\
\hline BM eosinophil (\%) & 3 & 3 & 6 & 6 & 15 & 8.5 & 13 \\
\hline BM dysplasia & $\begin{array}{l}\text { Atypical } \\
\text { mega- } \\
\text { karyocytic } \\
\text { hyperplasia }\end{array}$ & $\begin{array}{l}\text { Atypical } \\
\text { mega- } \\
\text { karyocytic } \\
\text { hyperplasia }\end{array}$ & $\begin{array}{l}\text { Atypical } \\
\text { mega- } \\
\text { karyocytic } \\
\text { hyperplasia }\end{array}$ & Dysmegakaryopoiesis & See text & See text & See text \\
\hline PB basophil (\%) & NR & NR & NR & NR & 38 & 70 & $54-65$ \\
\hline PB dysplasia & NR & NR & NR & NR & See text & See text & See text \\
\hline Toluidine blue & NP & NP & NP & NP & NP & Positive & Positive \\
\hline $\begin{array}{l}\text { Antigen } \\
\text { expression by flow } \\
\text { cytometry }\end{array}$ & NP & NP & NP & NP & $\begin{array}{l}\text { CD11a, CD11b, } \\
\text { CD13, CD18, } \\
\text { CD33, CD45, } \\
\text { CD123 }\end{array}$ & $\begin{array}{l}\text { CD10 (dim), } \\
\text { CD11c (dim), } \\
\text { CD13, CD15, } \\
\text { CD22 (dim), CD25, } \\
\text { CD33, CD38, } \\
\text { CD45, CD123, } \\
\text { MP0, IgDR }\end{array}$ & $\begin{array}{l}\text { CD10 (dim), CD11c } \\
\text { (dim), CD13, CD15, } \\
\text { CD22 (dim), CD25, } \\
\text { CD33, CD38, } \\
\text { CD45, CD123, } \\
\text { MP0, IgDR, CD117 }\end{array}$ \\
\hline $\begin{array}{l}\text { Cytogenetic } \\
\text { findings }\end{array}$ & $+8,11 q-$ & $|-7,-7|-4$ & $46, X Y$ & $46, X Y$ & \begin{tabular}{|l|}
$46, X Y, t(5 ; 12)$ \\
$(q 31 ; p 13)$
\end{tabular} & $\begin{array}{l}47, X X, \operatorname{der}(6) \\
t(6 ; ?)(q 25-27 ; ?) \\
+\operatorname{mar}(16)\end{array}$ & $\begin{array}{l}47, X X, \operatorname{der}(6) \\
t(6 ; ?)(q 25-27 ; ?) \\
\operatorname{der}(17) t(17 ; ?) \\
(p 13 ; ?)+\operatorname{mar}(16)\end{array}$ \\
\hline $\begin{array}{l}\text { Molecular genetic } \\
\text { studies }\end{array}$ & - & - & - & - & $\begin{array}{l}\text { Absence of } \\
\text { JAK2, (V617F) } \\
\text { mutation, } \\
\text { BCR/ABL } \\
\text { rearrange- } \\
\text { ment by PCR }\end{array}$ & $\begin{array}{l}\text { IL-6 gene } \\
\text { expression } \\
\text { in neoplastic } \\
\text { basophils and } \\
\text { absence of } \\
\text { JAK2 mutation } \\
\text { detected by real } \\
\text { time PCR }\end{array}$ & $\begin{array}{l}\text { Heterozygote } \\
\text { substitution } \\
\text { of C1650A }>\text { T } \\
(\text { K550N) on exon } \\
11, \text { wild type } \\
\text { sequence on exons } \\
9,13,17 \text {. Absence } \\
\text { of PIF1L1-PDGFRA } \\
\text { rearrangement }\end{array}$ \\
\hline IL-6 (pg/mL) & NP & NP & NP & NP & NP & 15.8 & 38.5 \\
\hline Tryptase ( $\mu \mathrm{g} / \mathrm{L})$ & NP & NP & NP & NP & NP & NP & $42.9-51.2$ \\
\hline Treatments & ALLO-SCT & $\begin{array}{l}\text { Hydroxyurea } \\
\text { prednisone }\end{array}$ & Imatinib & ALLO-HSCT & Hydroxyurea & Hydroxyurea & $\begin{array}{l}\text { Hydroxyurea, } \\
\text { Imatinib, } \\
\text { Etoposide, } \\
\text { Leukapheresis, } \\
\text { Prednisone CTX, } \\
\text { RBC transfusion }\end{array}$ \\
\hline $\begin{array}{l}\text { Follow-up } \\
\text { (months) }\end{array}$ & 35 , alive & 48 , dead & 2, alive & 10, dead & 9, dead & $>50$, alive & 5, dead \\
\hline
\end{tabular}


$2 \mathrm{~h}$. Physicians were misled in making a differential diagnosis of familial Mediterranean fever because they relied on differential counts made by ABCCs [4]. However, manual differential counts made on PB smears during a febrile episode revealed that the ABCCs wrongly characterized $70 \%$ of basophils as neutrophils; this was confirmed by toluidine blue stain and antigen expression by flow cytometric analysis. Marked elevation in plasma interleukin-6 (IL6) level of $15.8 \mathrm{pg} / \mathrm{mL}$ (normal: $<5.8 \mathrm{pg} / \mathrm{mL}$ ) was detected during the febrile episode. Real-time polymerase chain reaction showed IL-6 gene expression in neoplastic basophils, revealing that IL-6 was released from neoplastic basophils infiltrating the BM [4] (Table 1). IL-6 production and release by normal human basophils has not been reported in the literature [10].

\section{Values of PB and BM Basophil Percentages in the Diagnosis of CBL}

As shown in Tables 1 and 2, BM basophil percentages of 15\%, $26 \%$, and $20 \%$ in 3 of 4 patients with primary CBL were reported by Pardanani et al. [2]. These values are almost equal to the BM basophil percentage of $\geq 20 \%$ in $11 \%$ of 25 patients in the accelerated phase of CML reported by Kantarjian et al. [11] and also BM basophil percents greater than 1\% (range 1 to 27\%) in 34 cases and median 19\% (range 14 to 27\%) in 6 patients (in 4 of whom toluidine blue staining was positive) were reported by Hoyle et al. [12] in their series of 750 patients with acute myeloid leukemia. However, the BM basophil percentages in patients reported by Pardanani et al. [2] were markedly lower compared to the BM basophil percentages $(40 \%, 75 \%)$ of two patients in the chronic phase $[3,4]$ and the value recorded $(51 \%)$ in a patient in the accelerated phase of primary CBL [5] (Table 1). BM basophil percentages of $55 \%, 51.4 \%, 63 \%, 72 \%$, and $66 \%$ in six patients with secondary CBL were also respectively recorded (Table 2) $[6,7,8,9]$.

\section{Dysplastic Changes in Primary CBL}

In Case \#5, a patient with primary $\mathrm{CBL}$, dysplasia in the PB smear included hypogranular basophils with small and fine granulations and nuclear hyperlobation. In the BM smear, an increase in cellularity and megakaryocytes and hypogranular, agranular, and hypersegmented forms of basophils and eosinophils with coarse granulations and nuclear hyperlobation in addition to megakaryocytes with many small and hypolobated forms were reported [3].

In Case \#6, a patient with primary CBL in the chronic phase, dysplasia appeared as basophils with coarse basophilic granules, occasionally hypersegmented or giant segmented, and band forms of basophils in PB smear [4].

In the BM smear, an increase in cellularity, megakaryocytes, eosinophils, and prominent basophilic hyperplasia with the presence of all stages of maturation that resulted in marked neutrophilic suppression and mild suppression in erythroid lineages were noted. Three-lineage dysplasia manifested as hyposegmented basophils, giant segmented bands, and metamyelocyte forms of basophils and hypogranular basophilic metamyelocytes were noted. Dysplasia seen in eosinophils included binuclear metamyelocyte and myelocyte forms of eosinophils and large eosinophilic myelocytes. Occasional binuclear (Figure 1A) and multinuclear red cell precursors were also noticed. In addition, binuclear agranular immature megakaryocytes, mononuclear giant forms of megakaryocytes, and megakaryocytes with nuclear hyperlobation were observed. Toluidine blue stain showed red (metachromatic) granular staining in about $75 \%$ of non-erythroid granular cells in the marrow fields (Figure 1B).

\section{Dysplastic Changes in the Accelerated Phase of Primary CBL}

Clinical and hematologic features of the accelerated phase of primary CBL were only observed by Cehreli et al. [5] in their patient in the chronic phase of primary CBL (Case \#6) after 53 months of hematologic remission; this is shown as Case \#7 in Table 1. She presented with symptoms of anemia and was found to have relapse of her CBL and development of systemic mastocytosis (SM) as a secondary neoplasia. Three months later, the patient showed a rapid downhill clinical course when transformation of primary $\mathrm{CBL}$ to the accelerated phase with simultaneous occurrence of mast cell leukemia (MCL) was detected [5]. She experienced febrile episodes with abdominal pain during the accelerated phase of primary CBL with MCL. Although mast cells and eosinophils were shown to produce IL-6 [10], no febrile episodes were observed despite increases in mast cell (MC) counts to $3 \times 10^{9} / \mathrm{L}$ and eosinophil counts to $5.3 \times 10^{9} / \mathrm{L}$ unless her basophil counts climbed to $>40 \times 10^{9} / \mathrm{L}$ when prominent elevation in IL-6 level $(38.5 \mathrm{pg} / \mathrm{mL})$ was found. In a Wright-stained BM smear, basophilic hyperplasia with the presence of all stages of maturation that resulted in marked suppression in neutrophilic and erythroid lineages in addition to aggregates of MCs with a new and undefined MC morphology were demonstrated. MCs have round or oval nuclei, one or more nucleoli in immature forms, and mixed orange and dark purplish to black round cytoplasmic granules (Figure 2A). Tryptase immunohistochemical staining of the PB smear showed round, brown, granular cytoplasmic staining in the aggregates of the cells, confirming that these cells demonstrated tryptase activity and represented MCs (Figure 2B), because $\beta$-tryptase is a natural serine protease and is the most abundant mediator stored in the granules of MCs [13]. Three-lineage dysplasia manifested as giant hypersegmented basophils, giant binuclear metamyelocytes, binuclear hypogranular basophilic metamyelocytes, binuclear erythroblasts, and Pelger-Hüet anomalies were noted. Additionally, marked pyknosis, manifested as a decrease in both cellular and nuclear sizes, resulted in dense chromatin clumping, inducing a nuclear appearance that resembled a chromatin mass. Pyknotic myelocytes, metamyelocytes, binuclear basophilic metamyelocytes, and drum stick-like nuclear sticks in both pyknotic eosinophils and basophils were observed (Figure 2A). Dysplastic changes in the megakaryocytic lineage were similar to those seen in the chronic phase of the patient [4].

Marked pyknotic changes in the accelerated phase of primary CBL [5] have not been reported in patients with the chronic phase of primary $\mathrm{CBL}[3,4]$ as well as in patients with the accelerated $[5,7,8]$ and chronic phase [9] of secondary CBL in the literature. 


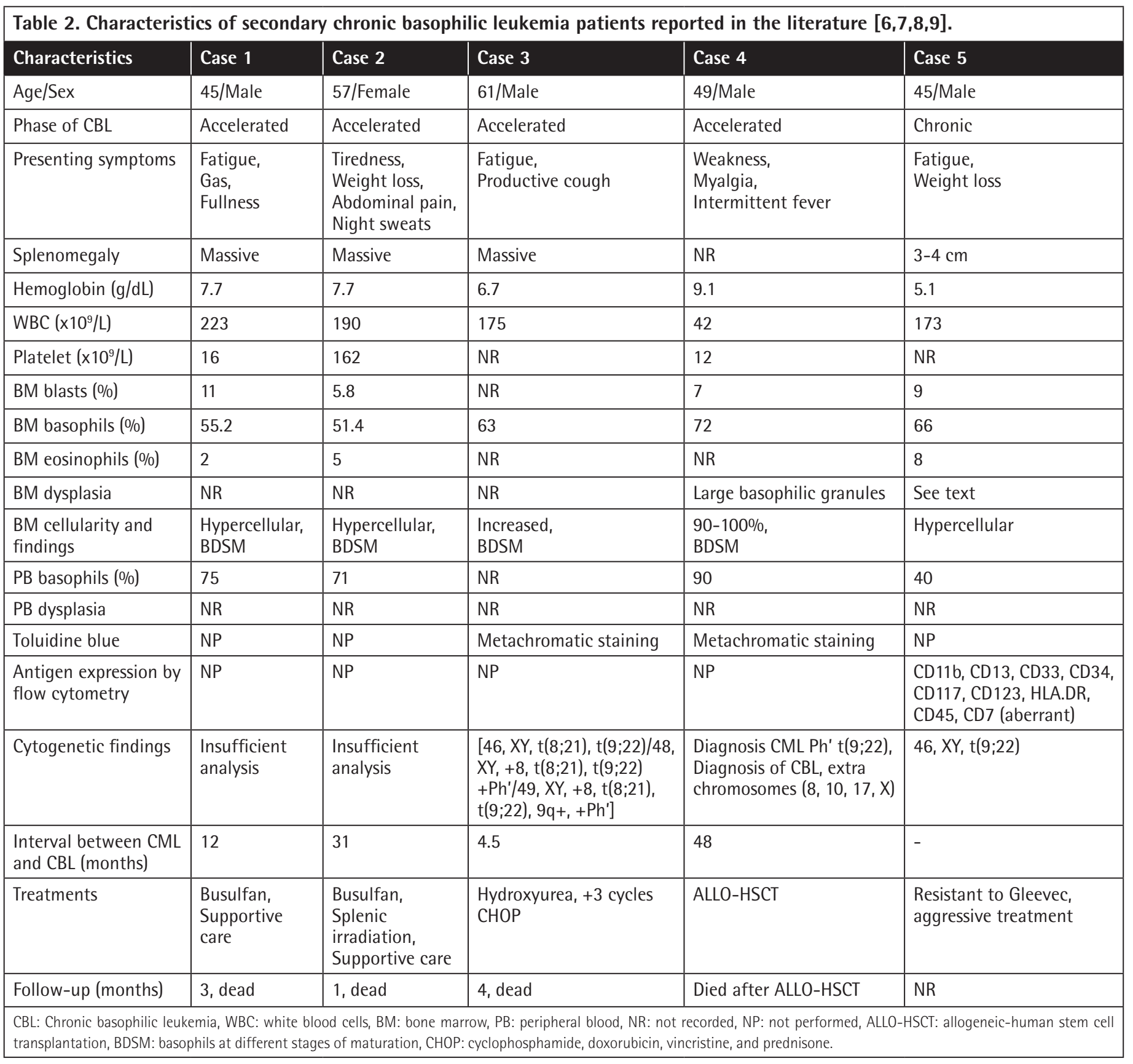

\section{Dysplastic Changes in the Chronic and Accelerated Phases of Secondary CBL}

Case \#5 in Table 2 was the only patient in the chronic phase of secondary CBL presenting with dysplasia. Diagnosis of CML may possibly be made when transformation of CML to CBL occurs; in this case, the patient had marked basophilia with the presence of 40\% and 66\% basophils in PB and BM, respectively, and antigen expressions by flow cytometric analysis revealed the nature of cells as basophils. Dysplasia included cytoplasmic hypogranulation or agranulation and nuclear hypersegmentation, eosinophils with abnormal granulation and nuclear hyperlobation, and dyserythropoiesis [9]. No dysplastic findings have been reported in patients in the accelerated phase of secondary CBL $[6,7,8]$ (Table 2).

\section{Confirmatory Laboratory Studies}

Both basophils and MCs have electron-dense cytoplasmic granules and produce numerous mediators such as histamine common to both cells. They also both show metachromatic staining with basic dyes, toluidine blue, and Alcian blue [1]. Toluidine blue stain showed a red (metachromatic) granular cytoplasmic staining in both basophils and MCs (Figure 1B) $[4,5,14,15]$. Peroxidase stain showed black granular cytoplasmic staining in basophils, but MCs do not contain myeloperoxidase and showed negative activity by peroxidase stain (Figure 2C) [16]. Flow cytometric analysis of mononuclear cells (MNCs) of the BM using monoclonal antibodies against the following antigens in Cases \#6 and \#7 showed that antigen expressions were positive for CD10 (dim), CD11c (dim), CD13, CD15, CD22 (dim), CD25, CD33, CD38, CD45, CD123, 
immunoglobulin D ( $\operatorname{gg} D)$ receptor, and myeloperoxidase and negative for HLA-DR, CD7, CD34, CD71, and CD117 with aberrant expression of CD10 $[17,18]$, thus revealing that the neoplastic cells were basophils.

Expression of the $\lg D$ receptor on normal basophils was demonstrated by Chen and Cerutti [19] and was also shown on neoplastic basophils by Cehreli et al. $[4,5]$.

\section{Importance of Confirmatory Laboratory Studies for the Diagnosis of CBL}

Tang et al. [3] and Vaidya et al. [9] reported that automated hematology analyzers did not characterize cells as basophils, but simply flagged them. Flow cytometric immunophenotyping became particularly important in confirming the nature of cells as basophils [9]. Cehreli et al. [4,5] reported that ABCCs, even with advanced technology, wrongly characterized basophils as neutrophils, misleading physicians in making differential diagnosis when the physicians relied on differential counts made by ABCCs. These reported observations suggest that manual differential counts should be seen before making a decision for diagnosis and also confirmed by metachromatic staining with toluidine blue stain in $\mathrm{PB}$ or BM smears and antigen expressions by flow cytometric analysis in BM MNCs to make an accurate diagnosis of CBL. The authors also proposed that neoplastic basophils with coarse, dark purple basophilic granules as demonstrated in Figure 1A may possibly mimic neutrophils with toxic granules [5]. Neutrophils usually contain light purplish-blue fine granules on Wright-stained PB smears (Figure 1A). Interestingly, in 1932, Kugel and Rosenthal [20] found that during bacterial infections fine neutrophilic granules are replaced by large, dark, irregular basophilic granules, which are called toxic granules, compared to the fine granules of the neutrophils.

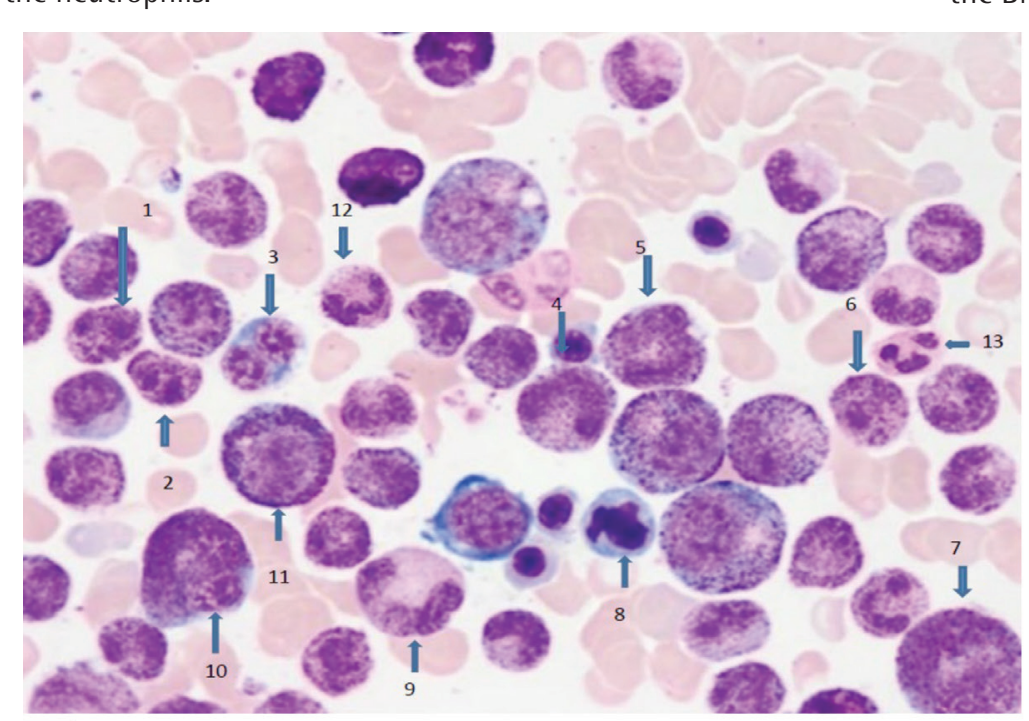

A

\section{Oscillation in Leukocyte Counts}

Similar to cyclic oscillations in leukocyte (neutrophil) counts reported in patients with $\mathrm{CML}[21,22]$, cyclic oscillations in basophil counts with simultaneous elevations in CRP levels and association with febrile episodes were only demonstrated by Cehreli et al. [5] in patients with primary $\mathrm{CBL}$ [4], but not reported in patients with primary [3] and secondary $\mathrm{CBL}[6,7,8,9]$.

Literature findings reveal that the diagnosis of $\mathrm{CBL}$ is mainly based on basophil morphology and increase in PB and BM basophil percentages. The literature also suggests that higher BM and PB basophil percentages are required to establish a satisfactory morphologic diagnosis of CBL. Based on the reported literature findings $[2,3,4,5,6,7,8,9]$, diagnostic criteria for $C B L$ as shown in Table 3 can be proposed.

\section{Differential Diagnosis}

The presence of an increase in megakaryocytes with atypical megakaryocytic hyperplasia and BM basophil percentages of less than $40 \%$ in 3 of four patients (Cases \#1-3), the absence of diagnostic confirmatory laboratory studies (Table 1), and an abnormal pattern of perivascular atypical MC infiltration detected by tryptase immunohistochemical staining (Cases \#2 and \#4) suggesting concurrent $\mathrm{MC}$ disease were reported as primary CBL by Pardanani et al. [2]. These findings created diagnostic problems in classifying the cases as primary $\mathrm{CBL}$ as described by Pardanani et al. [2] because according to the proposed diagnostic criteria for $\mathrm{CBL}$ (Table 3) BM basophil percentages were less than $\geq 40 \%$, increased megakaryocytes with dysplasia have been described in patients with essential thrombocythemia and chronic idiopathic myelofibrosis [23], and presence of abnormal pattern of perivascular atypical MC infiltration detected by tryptase immunohistochemical staining in the BM biopsy is one of the diagnostic criteria for SM [24].

Figure 1. A) Showing hyposegmented basophils $(1,2,6)$, binuclear erythroblast $(3)$, giant forms of basophilic bands $(4,5)$, large eosinophilic myelocyte (7), erythroblast with dysplastic nucleus (8), giant basophilic hypogranular metamyelocyte (9), giant binuclear basophilic metamyelocyte (10), basophilic myelocyte (11), neutrophilic band (12), segmented neutrophil (13) in chronic phase of primary chronic basophilic leukemia (Wright's stain, 100x); B) Demonstrating red color (metachromatic) granular cytoplasmic staining in 70\% nucleated cells of the bone marrow (toluidine blue stain, 100x). 
Dysplastic changes described in two patients in the chronic phase of primary $C B L[3,4]$ and in a patient in the accelerated phase of primary $\mathrm{CBL}$ [5] (Table 1) in addition to a patient in the chronic phase of secondary CBL [9] (Table 2) were not specific for CBL and have been described in patients with myelodysplastic syndrome (MDS) $[25,26]$. In MDS, dysplastic changes are accompanied by specific cytogenetic abnormalities [25], whereas cytogenetic studies specific for primary and secondary CBL have not been reported in the literature $[2,3,4,5,6,7,8,9]$. Additionally, laboratory studies with metachromatic staining by toluidine blue stain in both primary and secondary CBL $[4,5,7,8]$ and antigen expressions detected by flow cytometric analysis in both primary and secondary $\mathrm{CBL}[3,4,5,9]$ are confirmatory for diagnosis of CBL (Tables 1 and 2), but have no diagnostic value in patients with MDS $[25,26]$. Patients in the chronic and accelerated phases of CML associated with both PB

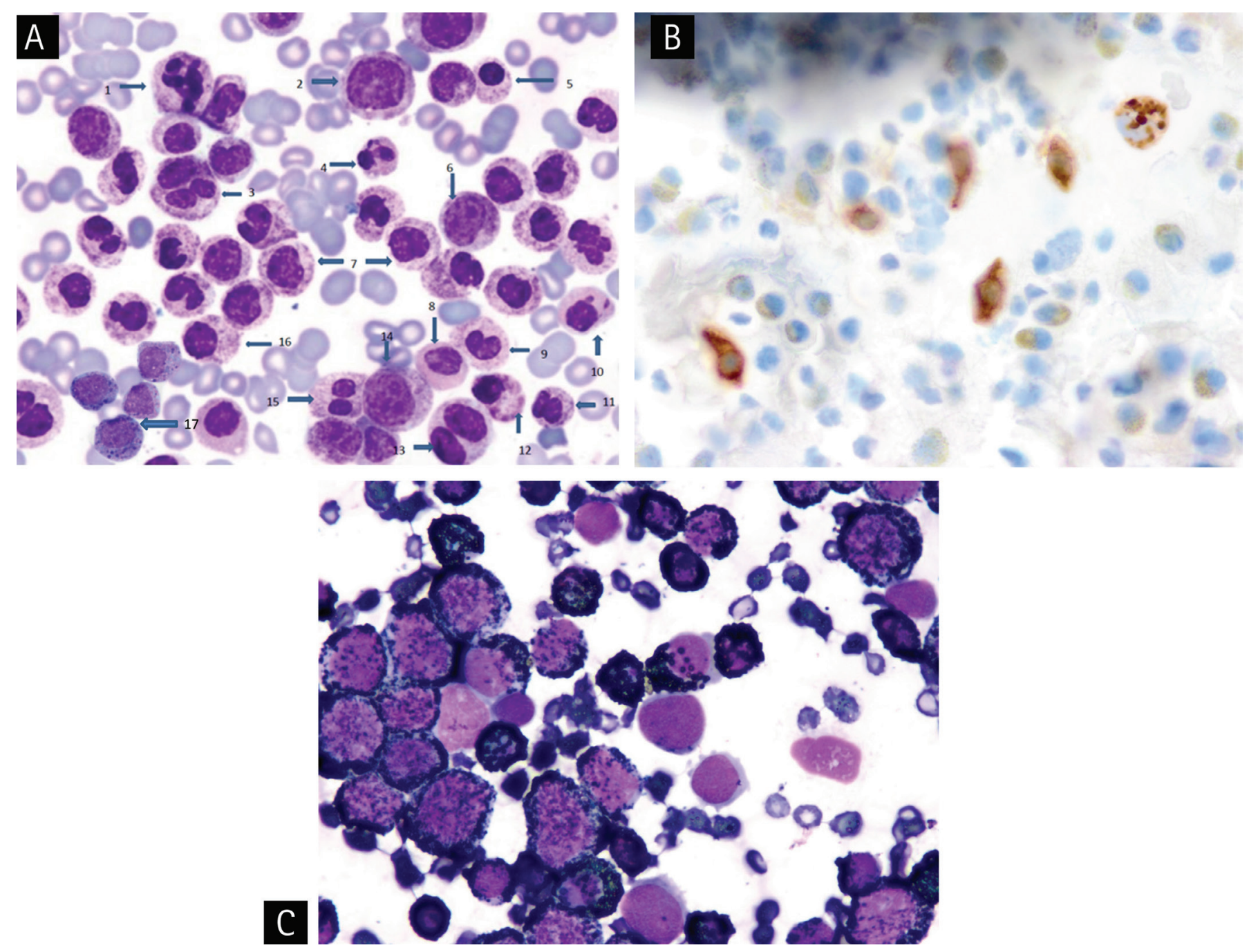

\begin{tabular}{|c|c|}
\hline & Diagnostic criteria \\
\hline $\mathrm{CBL}$ & $\begin{array}{l}\text { - Hypercellularity of bone marrow, } \\
\text { - Increase in megakaryocytes, } \\
\text { - Eosinophilia, } \\
\text { - Blasts }<10 \% \text {, } \\
\text { - BM and PB basophils } \geq 40 \% \text {, } \\
\text { - Prominent basophilic hyperplasia with presence } \\
\text { of all stages of maturation that result in moderate } \\
\text { to marked suppression in neutrophilic lineage }\end{array}$ \\
\hline Primary CBL & No previous hematologic neoplasia \\
\hline Secondary CBL & Known previous hematologic neoplasia \\
\hline
\end{tabular}

Figure 2. A) Demonstrating hypersegmented basophil (1), basophilic myelocyte (2), giant binuclear basophilic metamyelocyte (3), pyknotic eosinophil and basophil with drum-stick like nuclear sticks $(4,10)$, normal basophilic metamyelocyte $(6)$, pyknotic myelocyte, metamyelocytes, binuclear basophilic metamyelocyte and basophilic myelocyte $(5,7,11,12,16)$, agranular and hypogranular metamyelocyte $(8,9)$, binuclear hypogranular metamyelocyte (13), basophilic myelocyte (14), Pelger-Hüet anomaly (15) and aggregates of mast cells having mixed orange and dark purplish to black color round cytoplasmic granules (17) in accelerated phase of primary chronic basophilic leukemia with mast cell leukemia (Wright's stain, 100x); B) Showing tryptase activity in the round, brown color of cytoplasmic granules of mast cells demonstrated by immunohistochemical staining for tryptase. (tryptase immunohistochemical staining, 100x); C) Demonstrating black granular cytoplasmic staining by peroxidase stain in myeloperoxidase-positive basophils and absence of staining in aggregates of cells representing myeloperoxidase-negative mast cells in the bone marrow (peroxidase stain, 100x). 
and BM basophil percentages of $\geq 40 \%[6,7,8,9]$, patients with autoinflammatory diseases manifesting with recurrent attacks of fever and abdominal pain [27] and additionaly, chronic myeloproliferative disorders [28], mastocytosis variants [29], Castleman's disease [30] and the possibility of underlying CBL $[4,5]$ should be considered in the differential diagnosis in the patients presented with progressive leukocytosis associated with eosinophilia and elevations in IL-6 and CRP levels.

\section{Conclusion}

ABCCs may not characterize cells as basophils in patients with primary and secondary CBL $[3,4,5,9]$ and may mislead physicians in making a differential diagnosis [4]. The new generation of blood cell counters could be designed to contain toluidine blue stain for the detection of neoplastic basophils, and MCs with atypical or new MC morphology will be beneficial in leading physicians to make a reliable differential diagnosis, like ABCCs containing methylene blue stain for reticulocyte counts. Diagnosis, treatment, and follow-up should be performed with the guidance of manual differential counts in cases of primary and secondary CBL. The frequency and type of dysplastic changes $[3,4]$ observed, especially during the accelerated phase of primary CBL [5] (Figures 1 and 2), are comparable to those seen in patients with MDS and may create problems in the differential diagnosis of MDS $[25,26]$.

\section{Ethics}

Conflict of Interest: The author of this paper has no conflicts of interest, including specific financial interests, relationships, and/or affiliations relevant to the subject matter or materials included.

\section{References}

1. Beafus AD, Denburg JA. Basophilic leukocytosis: mast cells and basophils. In: Greer JP (ed). Wintrobe's Clinical Hematology, Twelfth Edition, Volume One. Philadelphia, Wolters Kluwer/Lippincott Williams \& Wilkins, 2009.

2. Pardanani AD, Morice WG, Hoyer JD, Tefferi A. Chronic basophilic leukemia: a distinct clinico-pathologic entity. Eur J Haematol 2003;71:18-22.

3. Tang G, Woods $\sqcup$, Wang SA, Brettler D, Andersen M, Miron PM, Pechet L, Woda BA, Hao S. Chronic basophilic leukemia: a rare form of chronic myeloproliferative neoplasm. Hum Pathol 2009;40:1194-1199.

4. Cehreli C, Ates H, Cehreli R, Sercan Z, Demirkan F. New paraneoplastic syndrome in chronic basophilic leukemia. Int J Hematol 2013;97:498-504.

5. Cehreli C, Alacacioglu I, Piskin O, Ates A, Cehreli R, Calibasi G, Yüksel E, Ozkal $\mathrm{S}$, Ozsan GH. Mast cell leukemia associated with undefined morphology and chronic basophilic leukemia. BMC Hematol 2014;14:17.

6. Kyle RA, Pease GL. Basophilic leukemia. Arch Intern Med 1966;118:205-210.

7. Xue Y, Guo Y, Lu D, Gu J, Lu D, Gong J, Wang M, Zhu W, Lin B. A case of basophilic leukemia bearing simultaneous translocation $t(8 ; 21)$ and $t(9 ; 22)$. Cancer Genet Cytogenet 1991;51:215-221.

8. Cunningham MT, Ganguly S. Chronic myeloid leukemia in accelerated phase with basophilic transformation of the bone marrow. Am J Hematol 2006;81:380-381.

9. Vaidya $S$, Madkaikar M, Ghosh K, Vundinti BR. Deletion of $A B L / B C R$ on $\operatorname{der}(9)$ associated with severe basophilia. Indian J Hum Genet 2011;17:100103.
10. GuzmánC,Hallal-CallerosC,López-Griego L, Morales-Montor J.Interleukin-6: a cytokine with a pleiotropic role in the neuroimmunoendocrine network. Open Neuroendocrinology 2010;3:152-160.

11. Kantarjian HM, Dixon D, Keating MJ, Talpaz M, Walters RS, McCredie KB, Freireich EJ. Characteristics of accelerated disease in chronic myelogenous leukemia. Cancer 1988;61:1441-1446.

12. Hoyle CF, Sherrington PD, Fischer $P$, Hayhoe FG. Basophils in acute leukemia. J Clin Pathol 1989;42:785-792.

13. Payne V, Kamp PC. Mast cell tryptase: a review of its physiology and clinical significance. Anesthesia 2004;59:695-703.

14. Perkins SL. Examination of the blood and bone marrow. In: Greer JP (ed). Wintrobe's Clinical Hematology, Twelfth Edition, Volume One. Philadelphia, Wolters Kumer/Lippincott Williams \& Wilkins, 2009.

15. Daniel MT, Flandrin G, Bernard J. Leucémie aiguë a mastocytes: etude cytochimique et ultrastructurale, à propos d'une observation. Nouv Rew $\mathrm{Fr}$ Hematol 1975;15:319-332.

16. Pinkus GS, Pinkus JL. Myeloperoxidase: a specific marker for myeloid cells in paraffin section. Mod Pathol 1991;6:733-741.

17. Han X, Jorgensen JL, Brahmandam A, Schlette E, Huh YO, Shi Y, Awagu S, Chen $W$. Immunophenotypic study of basophils by multiparameter flow cytometry. Arch Pathol Lab Med 2008;132:813-819.

18. Toba K, Koike T, Shiabata A, Hashimoto S, Takahashi M, Masuko M, Azegami T, Takahashi H, Aizawa Y. Novel technique for the direct flow cytoflourometric analysis of human basophils in unseparated blood and bone marrow and the characterization of phenotype and peroxidase of human basophils. Cytometry 1999;35:249-259.

19. Chen $K$, Cerutti A. The function and regulation of immunoglobulin D. Curr Opin Immunol 2011;23:345-352.

20. Kugel MA, Rosenthal N. Pathologic changes occuring in polymorphonuclear leukocytes during the progress of infections. Am J Med Sci 1932;183:657667.

21. Gatti RA, Robinson WA, Deinard AS, Nesbit M, McCullough JJ, Ballow M, Good RA. Cyclic leukocytosis in chronic myelogenous leukemia: new perspectives on pathogenesis and therapy. Blood 1973;41:771-782.

22. Mehta BC, Agarwal MB. Cyclic oscillations in leukocyte count in chronic myeloid leukemia. Acta Haematol 1980;63:68-70.

23. George TI. Pathology of myeloproliferative disorders. In: Greer JP (ed). Wintrobe's Clinical Hematology, Twelfth Edition, Volume One. Philadelphia, Wolters Kluwer/Lippincott Williams \& Wilkins, 2009.

24. Pardanani A. Systemic mastocytosis in adults: 2012 update on diagnosis, risk stratification, and management. Am J Hematol 2012;87:401-411.

25. Bennett JM, Catovsky D, Daniel MT, Flandrin G, Galton DA, Gralnick HR, Sultan C. Proposals for the classification myelodysplastic syndromes. FrenchAmerican-British (FAB) Cooperative Group. Br J Haematol 1982;51:189-199.

26. Vardiman JW, Thiele J, Arber DA, Brunning RD, Borowitz MJ, Porwit A, Harris $\mathrm{NL}$, LeBeau MM, Hellström-Lindberg E, Tefferi A. The 2008 revision of the World Health classification of myeloid neoplasms and acute leukemia: rationale and important changes. Blood 2009;114:937-951.

27. Touitou S. Autoinflammatory diseases. Best Pract Res Clin Rheumatol 2008;22:811-829.

28. Panteli KE, Hatzimicael EC, Bouranta PK, Katsaraki A, Seferiadis K, Stebbing J, Bourant KL. Serum interleukin (IL)-1, IL-2, sIL-2Ra, IL-6 and thrombopoietin levels in patients with chronic myeloproliferative diseases. $\mathrm{Br} \mathrm{J}$ Haematol 2005;130:709-715.

29. Brockow K, Akin C, Huber M, Metcalfe DD. IL-6 levels predict disease variant and extent of organ involvement in patients with mastocytosis. Clin Immunol 2005;115:216-223.

30. El-Osta HE, Kurzrock R. Castleman's disease: from basic mechanisms to molecular therapeutics. Oncologist 2011;16:497-511. 